\title{
Evaluation of BCG Vaccine Immunogenicity in Relation to Vitamin D Status in a Group of Egyptian Children
}

\section{Azza Abdelrahman Abdelgawad1*, Houda Abd El Azim Saoud2, Amal Gaber Mohamed2, Manal Ahmed Fathi', Entesar Raafat Mokhtar ${ }^{2}$}

${ }^{1}$ Research Institute of Ophthalmology, Giza, Egypt

${ }^{2}$ Faculty of Medicine for Girls Al-Azhar University, Cairo, Egypt

Email: ^drazza.rahman@hotmail.com

How to cite this paper: Abdelgawad, A.A., Saoud, H.A.E.A., Mohamed, A.G., Fathi, M.A. and Mokhtar, E.R. (2020) Evaluation of BCG Vaccine Immunogenicity in Relation to Vitamin D Status in a Group of Egyptian Children. Open Journal of Pediatrics, 10, 320-331.

https://doi.org/10.4236/ojped.2020.102033

Received: May 16, 2020

Accepted: June 16, 2020

Published: June 19, 2020

Copyright $\odot 2020$ by author(s) and Scientific Research Publishing Inc. This work is licensed under the Creative Commons Attribution International License (CC BY 4.0).

http://creativecommons.org/licenses/by/4.0/

\begin{abstract}
Background: Vitamin D has an immuomodulatory role in vaccine response and this may be mediated via its action on antigen presenting cells with the most potent effects on dendritic cells. Aim of work: was to determine if there is an association between circulating 25(OH)D concentrations and BCG vaccine cytokine response (interferon gamma) level. Methods: A cross sectional study included 80 infants aged 4 - 9 months from the pediatric outpatient clinic of Al-Zahraa university hospital (40 with normal weight and 40 with underweight). Participants were subjected to history taking, clinical examination, and laboratory investigations, particularly 25 hydroxy vitamin $\mathrm{D}[25(\mathrm{OH}) \mathrm{D}]$ and BCG vaccine-induced interferon gamma (IFN- $\gamma$ ). Results: The study showed that the underweight group had a lower socioeconomic level and higher percentage of breastfeeding compared with the normal weight group. Most infants in our study received vitamin D supplementation $(80 \%$ and $62.5 \%$ in normal and underweight groups, respectively). The average serum level of $25(\mathrm{OH}) \mathrm{D}$ was relatively high $(>100 \mathrm{ng} / \mathrm{ml})$ in both normal and underweight groups. The mean levels of IFN- $\gamma$ in response to BCG vaccine were not significantly different between the normal and underweight groups of infants in our study. Also, there was a statistically-significant moderate correlation between serum levels of 25(OH)D and BCG vaccine-induced IFN- $\gamma$ in both normal $(r=0.58)$ and underweight $(r=0.64)$ groups. Conclusion: A good vitamin $\mathrm{D}$ status was observed in all studied infants irrespective of their nutritional status and significant correlation with BCG vaccine induced IFN- $\gamma$.
\end{abstract}




\section{Keywords}

Vit D, BCG, Normal Weight, Underweight

\section{Introduction}

Vitamin D was first characterized like a vitamin in the 20th century and now it is recognized as a prohormone. Two major forms of vitamin D are vitamin D2 (ergocalciferol) and vitamin D3 (cholecalciferol). Vitamin D3 is synthesized in the skin of humans and is consumed in the diet via the intake of animal-based foods, mainly fish oils, whereas vitamin D2 is derived from plant sources, is not largely human-made, and added to foods. Vitamins D2 and D3 forms differ only in their side chain structure. The differences do not affect metabolism (i.e., activation), and both forms have the prohormone function.

Vitamin D obtained from sun exposure, food, and supplements is biologically inactive (either the vitamin D2 or D3) and must undergo activation through 2 consecutive enzymatic hydroxylation reactions occurring in the liver and kidney. Dietary vitamin D (either vitamin D2 or D3) is usually absorbed at the small intestine with other dietary fats. The presence of fats in the lumen triggers bile acids release, which initiate emulsification and support the formation of lipid-containing micelles, which diffuse into enterocytes. Once absorbed, exogenous vitamin D is packaged into chylomicrons, and thus is transported to the liver.

In recent years, researches have illuminated many functions of vitamin $\mathrm{D}$ other than its traditionally known roles in calcium homeostasis [1]. The important extra-skeletal action of vitamin $\mathrm{D}$ has now attracted tremendous interest [2]. Many cells from the innate and adaptive immune system express VDR. In addition, antigen presenting cells (macrophages and dendritic cells) and $\mathrm{T}$ and $\mathrm{B}$ lymphocytes express CYP27B1 (1-a - hydroxylase), which leads to local production of the active 1, 25- $(\mathrm{OH}) 2 \mathrm{D} 3$ from serum $25-(\mathrm{OH}) \mathrm{D}$, that lead to tissue intracrine and paracrine action. These immune cells express CYP27B1only when activated by invading organism. This facilitates enhanced generation of antimicrobial peptides cathelicidin and beta-definsin 2 [3]. Vitamin D has an immuomodulatory role in vaccine response and this may be mediated via its action on antigen presenting cells with the most potent effects on dendritic cells [4]. The aim of this study was to determine if there is an association between circulating 25(OH)D concentrations and BCG vaccine cytokine response (interferon gamma) level and to correlate between cytokine response to BCG vaccine, vitamin D concentration and nutrition status of those infants.

\section{Patients and Methods}

A cross sectional study that was carried on 80 infants aged 4 - 9 months, either nutritionally adequate or malnourished (simple underweight according to 
Wellcome classification [5]) with or without vitamin D supplies and were taken consecutively from paediatric department and pediatric outpatient clinic of Al-Zahraa University Hospital, Cairo, Egypt during the period from September 2018 to April 2019.

Inclusion criteria: all infants aged 4 - 6 months, either nutritionally adequate or not, with or without vitamin D supplementation

Exclusion criteria: Infants with severe or chronic illness, chronic renal failure, liver disease, severe injury and those who underwent major surgery.

They were classified into 2 groups: Group (1): 40 Egyptian infants aged 4 - 9 months nutritionally adequate with or without vitamin $\mathrm{D}$ supplementation and Group (2): 40 Egyptian infants aged 4 - 9 months nutritionally in adequate (simple underweight according to welcome classification [5]) with or without vitamin D supplementation.

All the studied children were subjected to:

1) Full history taking including: Dietetic history vaccination history, socioeconomic status, history of regular exposure to sun light and vitamin D supplementation.

Socioeconomic status was classified according to three factors: Income, occupation and education

Low: low income/occupation and low education

Moderate: low income/occupation and high education high income/occupation and low education

High: high income/occupation and high education

2) Clinical examination including: Anthropometric measurements, manifestation of infantile rickets or PEM and 3) Laboratory investigations: Routine: CBC with differential count done by automated coulter counter system, Blood urea and serum creatinine. Specific laboratory investigations which included $25(\mathrm{OH}) \mathrm{D}$ assay by enzyme-linked immune sorbent assay (ELISA) method (bioassay technology laboratory) and Interferon gamma assay by enzyme-linked immune sorbent assay (ELISA) method (bioassay technology laboratory).

Sample collection: $6 \mathrm{~mL}$ of venous blood were withdrawn and collected to into vacutainer tubes. Two $\mathrm{mL}$ was added to vacutainer tubes containing EISTA for the performance of CBC. $4 \mathrm{~mL}$ was added to vacutainer tubes containing gel blood was centrifuged at $1600 \mathrm{xg}$ for 15 minute $2 \mathrm{ml}$ of serum was collected to measure urea and create and the other two $\mathrm{mL}$ of serum was kept frozen at -20 degree Celsius till the assay was performed after al samples were collected from all the patients.

Principle of the test $(25(\mathrm{OH}) \mathrm{D}$ assays): This kit is an enzyme-linked immunosorbent assay (ELISA)Cat.No E1981Hu. The plate has been precoated with human 25-OH-D antibody present in the sample is added and binds to antibodies coated on the wells. And then bitoinylated human 25-OH-D antibody is added and binds to 25-OH-D in the sample. Then streptavidin-HRP is added and binds to biotinylated 25-OH-D antibody. After incubation unbound step, 
substrate solution is then added and color develops in proportion to terminated by is measured at $450 \mathrm{~nm}$.

Principle of the test (Interferon gamma assay): This kit is an enzyme-linked immunosorbent assay (ELISA)Cat No E0105Hu. The plate has been pre-coated with human INF-G antibody. INF-G present in the sample is added and binds to antibodies coated on the wells. And then biotinylated human INF-G antibody is added and binds to INF-G in the sample. Then streptavidin-HRP is added and binds to the biotinylated INF-G antibody. After incubation, unbound streptavidin-HRP is washed away during a washing step. Substrate solution is then added and color develops in proportion to the amount of human INF-G. The reaction is terminated by addition of acidic stop solution and absorbance is measured at $450 \mathrm{~nm}$.

Ethical consideration: An informed consent was obtained from parents of all patients before getting them involved in the study and confidentiality of all data were ensured any of patients has the right to withdraw from the study at any time without giving any reason.

\section{Statistical Analysis}

Data were collected, coded, revised and entered to the statistical package for Social Science (IBM SPSS) version 20. The data were presented as number and percentages for $\mathrm{h}$ qualitative data, mean, standard deviation and ranges for the quantitative data with parametric distribution and median with inter quartile range (IQR) for the quantitative data with non parametric distribution.

Chi-square test was used in the comparison between two groups with qualitative data and Fisher exact test was used instead of the Chi-square test when the expected count in any cell found less than 5. Independent $t$-test was used in the comparison between two groups with quantitative data and parametric distribution and Mann-Whitney test was used in the comparison between two groups with quantitative data and non parametric distribution. Spearman correlation coefficients were used to assess the significant relation between two quantitative parameters in the same group.

\section{Results}

In this study mean of age $\mathrm{z}$ score were 0 with range from -1.58 to 1.29 and mean of weight $\mathrm{z}$ score were 0 with range from -1.79 to 2.08 . There was statistically significant increase low socioeconomic in underweight group and statistically significant increase in normal weight group in comparison to under weight group with weight, length, weight $\mathrm{z}$ score and length $\mathrm{z}$ score.

This study showed statistically significant increase breast feeding in underweight group and increase formula feeding in normal weight group. Also, there was statistically significant increase with $\mathrm{Hb}$, urea and creat in normal weight group in comparison to under weight group.

In this study, there was no statistically significant difference between vit $\mathrm{D}$ and 
interferon regarding studied group

This study revealed that Vit D has positive correlation with Interferon and negative correlation with creat, interferon has positive correlation with Vit D and negative correlation with creat, vit $\mathrm{D}$ has positive correlation with Interferon and urea and interferon has positive correlation with Vit D (Tables 1-6).

Table 1. Comparison between normal weight group and underweight group as regards demographic data.

\begin{tabular}{|c|c|c|c|c|c|c|c|}
\hline \multicolumn{2}{|c|}{ Characteristics } & \multicolumn{2}{|c|}{$\begin{array}{l}\text { Normal weight } \\
(\mathrm{No},=40)\end{array}$} & \multicolumn{2}{|c|}{$\begin{array}{l}\text { Under weight } \\
(\mathrm{No},=40)\end{array}$} & \multicolumn{2}{|c|}{$\begin{array}{l}\text { Chi square test/ } \\
\text { Independent } t \text { test }\end{array}$} \\
\hline & & No & $\%$ & No & $\%$ & $\mathrm{x}^{2} / \mathrm{t}^{* *}$ & $\mathrm{p}$ value \\
\hline \multirow{3}{*}{ Sex } & Female & 14 & $35.0 \%$ & 17 & $42.5 \%$ & \multirow{2}{*}{0.474} & \multirow{2}{*}{0.491} \\
\hline & Male & 26 & $65.0 \%$ & 23 & $57.5 \%$ & & \\
\hline & $\begin{array}{c}\text { Low } \\
\text { Socioeconomic }\end{array}$ & 10 & $25.0 \%$ & 34 & $85.0 \%$ & \multirow{3}{*}{29.455} & \multirow{3}{*}{$<0.001$} \\
\hline \multirow[t]{2}{*}{ Socioeconomic } & $\begin{array}{c}\text { Moderate } \\
\text { Socioeconomic }\end{array}$ & 28 & $70.0 \%$ & 5 & $12.5 \%$ & & \\
\hline & $\begin{array}{c}\text { High } \\
\text { Socioeconomic }\end{array}$ & 2 & $5.0 \%$ & 1 & $2.5 \%$ & & \\
\hline Age $(\mathrm{m})$ & Mean \pm SD & \multicolumn{2}{|c|}{$6.80 \pm 1.80$} & \multicolumn{2}{|c|}{$6.70 \pm 1.70$} & $0.256^{\star *}$ & 0.799 \\
\hline Age $\mathrm{z}$ core & Mean \pm SD & \multicolumn{2}{|c|}{$0.28 \pm 1.03$} & \multicolumn{2}{|c|}{$-0.28 \pm 0.97$} & 0.256 & 0.799 \\
\hline Weight (kg) & Mean \pm SD & \multicolumn{2}{|c|}{$7.90 \pm 1.22$} & \multicolumn{2}{|c|}{$5.65 \pm 0.90$} & $9.438^{\star *}$ & $<0.001$ \\
\hline Length $(\mathrm{cm})$ & Mean \pm SD & \multicolumn{2}{|c|}{$67.50 \pm 4.15$} & \multicolumn{2}{|c|}{$59.78 \pm 3.52$} & $8.978^{\star *}$ & $<0.001$ \\
\hline Z score: weight (kg) & Mean \pm SD & \multicolumn{2}{|c|}{$0.73 \pm 0.78$} & \multicolumn{2}{|c|}{$-0.73 \pm 0.58$} & $9.438^{\star \star}$ & $<0.001$ \\
\hline Z score: length $(\mathrm{cm})$ & Mean \pm SD & \multicolumn{2}{|c|}{$0.71 \pm 0.76$} & \multicolumn{2}{|c|}{$-0.71 \pm 0.65$} & $8.978^{\star *}$ & $<0.001$ \\
\hline
\end{tabular}

This table showed that there was statistically significant increase low socioeconomic in underweight group and there was statistically significant increase weight, length, weight $\mathrm{z}$ score and length $\mathrm{z}$ score in normal weight group in comparison to underweight group.

Table 2. Comparison between normal weight group and underweight group as regards Vit D supply, diatetic history and exposure to sun.

\begin{tabular}{|c|c|c|c|c|c|c|c|}
\hline & \multirow[t]{2}{*}{ Items } & \multicolumn{2}{|c|}{$\begin{array}{l}\text { Normal weight } \\
\quad(\mathrm{No},=40)\end{array}$} & \multicolumn{2}{|c|}{$\begin{array}{l}\text { Under weight } \\
(\text { No, }=40)\end{array}$} & \multicolumn{2}{|c|}{$\begin{array}{l}\text { Chi square } \\
\text { Test }\end{array}$} \\
\hline & & No & $\%$ & No & $\%$ & $x^{2}$ & $\mathrm{p}$ value \\
\hline \multirow{2}{*}{$\begin{array}{l}\text { Vit D } \\
\text { Supply }\end{array}$} & No & 8 & $20.0 \%$ & 15 & $37.5 \%$ & \multirow{2}{*}{2.990} & \multirow{2}{*}{0.084} \\
\hline & Ok & 32 & $80.0 \%$ & 25 & $62.5 \%$ & & \\
\hline \multirow{2}{*}{$\begin{array}{l}\text { Diatetic } \\
\text { History }\end{array}$} & $\begin{array}{c}\text { Breast } \\
\text { milk feeding }\end{array}$ & 24 & $60.0 \%$ & 34 & $85.0 \%$ & \multirow{2}{*}{6.270} & \multirow{2}{*}{0.012} \\
\hline & $\begin{array}{c}\text { Milk } \\
\text { formula feeding }\end{array}$ & 16 & $40.0 \%$ & 6 & $15.0 \%$ & & \\
\hline \multirow{2}{*}{$\begin{array}{l}\text { Exposure } \\
\text { to sun }\end{array}$} & $\begin{array}{c}\text { Irregular } \\
\text { exposure to sun }\end{array}$ & 22 & $55.0 \%$ & 23 & $57.5 \%$ & \multirow{2}{*}{0.051} & \multirow{2}{*}{0.822} \\
\hline & $\begin{array}{l}\text { Regular exposure } \\
\text { to sun }\end{array}$ & 18 & $45.0 \%$ & 17 & $42.5 \%$ & & \\
\hline
\end{tabular}

This table showed that there was statistically significant increase in infants receiving breast feeding and more prevalent in under weight group while formula feeding are more prevalent in normal weight group. 
Table 3. Comparison between normal weight group and underweight group as regards rickets, $\mathrm{Hb}$, urea and creat.

\begin{tabular}{|c|c|c|c|c|c|c|c|}
\hline \multicolumn{2}{|c|}{ Items } & \multicolumn{2}{|c|}{$\begin{array}{l}\text { Normal weight } \\
(\mathrm{No},=40)\end{array}$} & \multicolumn{2}{|c|}{$\begin{array}{l}\text { Under weight } \\
(\mathrm{No},=40)\end{array}$} & \multicolumn{2}{|c|}{$\begin{array}{c}\text { Chi square test/ } \\
\text { Independent } t \text { test }{ }^{* *}\end{array}$} \\
\hline & & No & $\%$ & No & $\%$ & $\mathrm{x}^{2} / \mathrm{t}^{* *}$ & $\mathrm{p}$ value \\
\hline \multirow{3}{*}{ Rickets } & No & 35 & $87.5 \%$ & 31 & $77.5 \%$ & \multirow{3}{*}{1.385} & \multirow{3}{*}{0.239} \\
\hline & & & & & & & \\
\hline & Yes & 5 & $12.5 \%$ & 9 & $22.5 \%$ & & \\
\hline $\mathrm{Hb}(\mathrm{mg} / \mathrm{dl})$ & Mean \pm SD & \multicolumn{2}{|c|}{$10.95 \pm 0.85$} & \multicolumn{2}{|c|}{$9.09 \pm 0.90$} & $9.503^{* *}$ & $<0.001$ \\
\hline Urea (mg/dl) & Mean \pm SD & \multicolumn{2}{|c|}{$11.18 \pm 2.10$} & \multicolumn{2}{|c|}{$8.03 \pm 1.85$} & $7.127^{\star *}$ & $<0.001$ \\
\hline Creat $(\mathrm{mg} / \mathrm{dl})$ & Mean \pm SD & \multicolumn{2}{|c|}{$0.85 \pm 0.36$} & \multicolumn{2}{|c|}{$0.37 \pm 0.09$} & $8.220^{\star *}$ & $<0.001$ \\
\hline
\end{tabular}

This table showed that there was statistically significant increase in $\mathrm{Hb}$ concentration, urea and creat normal weight group in comparison to under weight group.

Table 4. Comparison between normal weight group and underweight group as regards Vit D and interferon.

\begin{tabular}{cccccccc}
\hline & \multicolumn{2}{c}{$\begin{array}{c}\text { Normal weight } \\
\text { Ino, }=40)\end{array}$} & \multicolumn{2}{c}{$\begin{array}{c}\text { Under weight } \\
(\mathrm{No},=40)\end{array}$} & \multicolumn{2}{c}{$\begin{array}{c}\text { Independent } \\
\text { t test }\end{array}$} \\
\cline { 2 - 7 } & Mean & $\mathrm{SD}$ & Mean & $\mathrm{SD}$ & $\mathrm{T}$ & $\mathrm{p}$ value \\
\hline Vit D $(\mathrm{ng} / \mathrm{ml})$ & 102.68 & 72.82 & 103.15 & 78.35 & -0.028 & 0.978 \\
Interferon $(\mathrm{ng} / \mathrm{ml})$ & 389.68 & 256.33 & 365.83 & 262.50 & 0.411 & 0.682 \\
\hline
\end{tabular}

This table showed that there was no statistically significant difference between vit $\mathrm{D}$ and interferon regarding studied group.

Table 5. Correlation between level of vit D, interferon and all studied parameters in normal weight group.

\begin{tabular}{ccccc}
\hline & \multicolumn{2}{c}{$\begin{array}{c}\text { Vit D } \\
(\mathrm{ng} / \mathrm{ml})\end{array}$} & \multicolumn{2}{c}{$\begin{array}{c}\text { Interferon } \\
\text { (ng/ml) }\end{array}$} \\
\cline { 2 - 5 } & $\mathrm{R}$ & $\mathrm{p}$ value & $\mathrm{R}$ & $\mathrm{P}$ value \\
\hline Interferon (ng/ml) & -0.015 & $<0.001$ & - & - \\
Vit D (ng/ml) & - & - & 0.577 & $<0.001$ \\
age (m) & 0.113 & 0.831 & -0.047 & 0.771 \\
weight (kg) & -0.114 & 0.221 & 0.013 & 0.935 \\
legnth (cm) & -0.398 & 0.342 & -0.015 & 0.927 \\
Hb (mg/dl) & -0.047 & 0.549 & 0.113 & 0.486 \\
urea (mg/dl) & 0.013 & 0.918 & -0.114 & 0.484 \\
creat (mg/dl) & -0.015 & 0.046 & -0.398 & 0.011 \\
\hline
\end{tabular}

This table showed that Vit D has positive correlation with Interferon and negative correlation with creat, Interferon has positive correlation with Vit $\mathrm{D}$ and negative correlation with creat. 
Table 6. Correlation between level of vit $\mathrm{D}$, interferon and all studied parameters in underweight group.

\begin{tabular}{ccccc}
\hline \multirow{2}{*}{ Parameters } & \multicolumn{2}{c}{ Vit D $(\mathrm{ng} / \mathrm{ml})$} & \multicolumn{2}{c}{ Interferon } \\
\cline { 2 - 5 } & $\mathrm{R}$ & $\mathrm{p}$ value & $\mathrm{R}$ & P value \\
\hline Interferon $(\mathrm{ng} / \mathrm{ml})$ & 0.644 & $<0.001$ & - & - \\
Vit D $(\mathrm{ng} / \mathrm{ml})$ & - & - & 0.644 & $<0.001$ \\
age $(\mathrm{m})$ & 0.092 & 0.574 & -0.088 & 0.588 \\
weight $(\mathrm{kg})$ & 0.045 & 0.781 & 0.023 & 0.887 \\
length $(\mathrm{cm})$ & 0.019 & 0.908 & -0.116 & 0.477 \\
Hb $(\mathrm{mg} / \mathrm{dl})$ & -0.040 & 0.807 & 0.087 & 0.595 \\
urea $(\mathrm{mg} / \mathrm{dl})$ & 0.379 & 0.016 & 0.287 & 0.072 \\
creat $(\mathrm{mg} / \mathrm{dl})$ & -0.082 & 0.616 & 0.275 & 0.086 \\
\hline
\end{tabular}

\section{Discussion}

Effective vaccination requires a good immune response to produce protective immune cells and/or immunoglobulins against future infections. However, several factors may affect immune status and response to vaccination, including nutritional status. Moreover, vitamin D has been found to have immunomodulatory effects and may affect the immune response to infections and vaccination [6]. In this cross-sectional study, we aimed at investigating the association among vitamin D status, cytokine response to BCG vaccination, and nutritional status in infants. We included 80 infants aged $4-9$ months from the pediatric department and pediatric outpatient clinic of Al-Zahraa university hospital (40 with normal weight and 40 with underweight). Study participants were subjected to history taking, clinical examination, and laboratory investigations, particularly serum circulating 25 hydroxy vitamin D [25(OH)D] and BCG vaccine-induced interferon gamma (IFN- $\gamma$ ).

Regarding epidemiological data, we found that infants in the underweight group had a lower socioeconomic level compared with that of the normal weight group. Egypt is one of the developing countries with a high rate of childhood malnutrition. As of 2014 data, the rates of underweight, wasting, and stunting in Egyptian children under five years were $6 \%, 8 \%$, and $21 \%$, respectively. Low socioeconomic status is associated with poor food security, poor environmental conditions, higher rate of infections, and lower educational levels of parents. All these factors contribute to malnutrition in infants and children [7] [8].

Lack of breastfeeding is an important cause of malnutrition in infants [9]. However, the percentage of breastfeeding in the underweight group (85\%) is higher than that in the normal weight group (65\%). Other factors, like the low socioeconomic status as discussed above, may have a more pronounced effect to the extent outweighing the benefits of breastfeeding; prolonged breastfeeding without proper weaning may also contribute [8] [9].

Most infants in our study received vitamin D supplementation $(80 \%$ and 
$62.5 \%$ in normal and underweight groups, respectively). This is in accordance with the current American Academy of Pediatrics recommendation, which state that all infants and children should have a minimum intake of 400 IU of vitamin $\mathrm{D}$ per day beginning soon after birth [10] [11].

In our study, rickets is identified in $12.5 \%$ and $22.5 \%$ of infants with normal and under-weight, respectively. Clinical diagnosis, by detecting the skeletal manifestations, is important particularly in developing countries with a high prevalence of rickets and limited resources. Of note, nutritional rickets frequently occurs in obese infants due to increased requirements of vitamin $\mathrm{D}$ because it is sequestrated in body fat [7] [11].

The lower levels of hemoglobin in infants with underweight could be attributed to the associated deficiencies of vitamins and minerals, particularly iron. [12].

On the other hand, both groups of infants have normal serum levels of urea and creatinine, but the normal weight group has a statistically significant higher level. Serum urea and creatinine are affected by several factors, such as age, gender, dietary intake, and body mass; the latter may obviously explain the difference between groups. Indeed, serum creatinine may be a poor indicator for impaired kidney function in patients with underweight/low body mass [13].

The average serum level of $25(\mathrm{OH}) \mathrm{D}$ was relatively high $(>100 \mathrm{ng} / \mathrm{ml})$ in both normal and underweight groups. Serum 25(OH)D remains the optimal indicator for vitamin D status thanks to its longer half-life. It may be difficult to specify the exact "normal" level of serum $25(\mathrm{OH}) \mathrm{D}$, but there is a consensus on defining levels below $12.5 \mathrm{ng} / \mathrm{ml}(30 \mathrm{nmol} / \mathrm{l})$ as vitamin $\mathrm{D}$ deficiency and between 12.5 $20 \mathrm{ng} / \mathrm{ml}$ (30 - $50 \mathrm{nmol} / \mathrm{ml})$ as vitamin D insufficiency [11] [14] [15]. Accordingly, none of infants in our study has vitamin D deficiency or insufficiency. This result disagrees with prior studies.

Two studies included Egyptian mothers and their infants. In one study, the average levels of $25(\mathrm{OH}) \mathrm{D}$ were $16.8 \mathrm{ng} / \mathrm{ml}$ and $3.2 \mathrm{ng} / \mathrm{ml}$ in mothers and infants, respectively [16]. In the other study, the mean level of $25(\mathrm{OH}) \mathrm{D}$ was 16.7 $\mathrm{ng} / \mathrm{ml}$ in infants. It is interesting that $40 \%$ of mothers in the last study had a $25(\mathrm{OH}) \mathrm{D}$ level of $<20 \mathrm{ng} / \mathrm{mL}$, although their mean level was higher at 32.6 $\mathrm{ng} / \mathrm{mL}$ because some cases had very high levels [17].

The higher mean level of vitamin $\mathrm{D}$ in our study could be attributed to vitamin D supplementation (more than $70 \%$ of cases) and regular sun exposure (more than $40 \%$ of cases). The recent guidelines emphasizing daily vitamin D supplementation since birth and increased awareness of the community may contribute to improved vitamin D status in infants and children compared with earlier studies [11]. However, we acknowledge that our results may not be generalizable, given the limited number of cases, and should be confirmed by prospective large-scale studies.

The mean levels of IFN- $\gamma$ in response to BCG vaccine were not significantly different between the normal and underweight groups of infants in our study. 
Results of IFN- $\gamma$ release assay in response to BCG vaccination are affected by several factors, such as ethnicity, genetic factors, and time-lapse since vaccination [18]. Tuberculosis is a major health concern all over the world. BCG vaccination has been proven to offer variable protection against tuberculous infection (27\%), active diseases (71\%), and progression from infection to active disease (58\%) [19]. BCG is included in the mandatory immunization program in Egypt [20].

Our study shows a statistically-significant moderate correlation between serum levels of 25(OH)D and BCG vaccine-induced IFN- $\gamma$ in both normal $(\mathrm{r}=$ $0.58)$ and underweight $(r=0.64)$ groups. This underscores the immunomodulatory role of vitamin $\mathrm{D}$ and its possible important effect on the immune response to vaccine [2] [21].

Vitamin D may affect the immune response to vaccination through activation of dendritic cells (via toll-like receptors by vaccine antigen \pm adjuvant) and intracellular upregulation of CYP27B1 with stimulation of cytokine production and T-cell proliferation. This results in suppression of Th1 response-like cytokines (IFN- $\gamma$, IL-2) and the increase of both Th2 (IL4, IL5, IL10, IL13) and Th17 (IL-17) response-like cytokines. Vitamin D may also affect the proliferation and antibody-production of B-cells. Despite $1 \alpha, 25(\mathrm{OH}) 2 \mathrm{D}$ may blunt B-cell functions, it may paradoxically stimulate a vaccine-induced immune response by its effect on innate immunity [2] [22].

There are several observational and clinical studies on the association between vitamin D status and vaccine effectiveness. However, the results are conflicting and reveal some methodologic weaknesses as well as limiting and confounding factors [21].

For example, in a retrospective study on 200 patients with chronic kidney disease, vitamin $\mathrm{D}$ deficiency was associated with poor antibody response to Hepatitis B vaccination [23]. However, in a randomized controlled trial on 31 hemodialysis patients with hepatitis B booster vaccine, the intravenous $4 \mu \mathrm{g}$ of paricalcitol (an active vitamin $\mathrm{D}$ analog) during hemodialysis three times weekly was compared with placebo. There was no difference in the in vivo memory response or in vitro proliferation and release of cytokines (IL-2, IL-6, TNF- $\alpha$, and INF- $\gamma$ ) [24].

Lalor et al. [22] compared the serum levels of 25(OH)D and IFN- $\gamma$ in BCG vaccinated and unvaccinated groups of infants at two points ( 3 and 12 months of age). There was a moderate inverse correlation between vitamin $\mathrm{D}$ status and IFN- $\gamma$ response to BCG vaccine at infants aged three months; infants with higher vitamin $\mathrm{D}$ levels have a lower IFN- $\gamma$ response. These results disagree with the positive correlation found in our study. Of note, the levels of $25(\mathrm{OH}) \mathrm{D}$ in this study were markedly low compared with that of our study. In addition, the correlation was weaker when assessed in infants at 12 months of age compared with that at 3 months of age [22].

Another interesting point in Lalor et al. [22] study is that BCG vaccinated infants had a six-time higher vitamin $\mathrm{D}$ level than that of unvaccinated infants. 
They proposed that mycobacterial antigens in BCG may increase the production of the 25 hydroxylase enzymes, resulting in increased production of $25(\mathrm{OH}) \mathrm{D}$ [22]. We did not include control (unvaccinated) cases in our study to investigate this point.

In a randomized control study in China, 597 infants with poor BCG vaccine response, as evidenced by Tuberculin Skin Test (TST), were revaccinated with BCG vaccine. Infants were divided into two groups, one of which (intervention group) received supplementation with combined vitamins D and A. TST was repeated after three months. Results show that supplementation with combined vitamins $\mathrm{D}$ and $\mathrm{A}$ improved immune response to $\mathrm{BCG}$ vaccination compared to control. However, levels of vitamin D or cytokines were not evaluated in this study [25].

Our study has some limitations. First, we assessed the immune response to BCG vaccination by only IFN- $\gamma$ release assay. Second, we assessed IFN- $\gamma$ level in infants aged 4 - 9 months. This might result in the variability of IFN- $\gamma$ levels, which are affected by time-lapse after BCG vaccination. Third, it would be meaningful to have a control group of unvaccinated infants. However, this was not applicable because BCG is a part of the Egyptian obligatory immunization schedule for all infants. Fourth, our study has a small number of cases. Results of our study need to be confirmed by future large-scale studies.

\section{Conclusion}

Our study showed a relatively good vitamin D status in included infants irrespective of their body weight; this may be attributed to vitamin $\mathrm{D}$ supplementation and regular exposure to sun. We found a statistically significant moderate correlation between vitamin D status and immune response to BCG vaccine (as assessed by IFN- $\gamma$ release assay). These results are important particularly for developing countries, where children are at high risk of both vitamin D deficiency and infections.

\section{Recommendations}

Screening and optimization of vitamin D status in infants and children with poor response to BCG vaccine as well as other vaccines, evaluation of immune response to BCG vaccine and other vaccines in infants and children with vitamin $\mathrm{D}$ deficiency and awareness of the health care personnel and community about the immunomodulatory role of vitamin $\mathrm{D}$ in infections and vaccination.

\section{Conflicts of Interest}

The authors declare no conflicts of interest regarding the publication of this paper.

\section{References}

[1] Haussler, M.R., Whitfield, G.K., Kaneko, I., et al. (2013) Molecular Mechanisms of 
Vitamin D Action. Calcified Tissue International, 92, 77-98.

https://doi.org/10.1007/s00223-012-9619-0

[2] Lang, P.O. and Aspinall, R. (2017) Vitamin D Status and the Host Resistance to Infections: What It Is Currently (Not) Understood. Clinical Therapeutics, 39, 930-945. https://doi.org/10.1016/j.clinthera.2017.04.004

[3] Bikle, D.D. (2010) Vitamin D: Newly Discovered Actions Require Reconsideration of Physiologic Requirements. Trends in Endocrinology \& Metabolism, 21, 375-384. https://doi.org/10.1016/j.tem.2010.01.003

[4] Penna, G. and Adorini, L. (2000) 1 Alpha,25-Dihydroxyvitamin D-3 Inhibits Differentiation, Maturation, Activation, and Survival of Dendritic Cells Leading to Impaired Alloreactive T Cell Activation. The Journal of Immunology, 164, 2405-2411. https://doi.org/10.4049/jimmunol.164.5.2405

[5] Bender, D.A. (2014) A Dictionary of Food and Nutrition. 4th Edition, Oxford University, Oxford.

[6] Bourke, C.D., Berkley, J.A. and Prendergast, A.J. (2016) Immune Dysfunction as a Cause and Consequence of Malnutrition. Trends in Immunology, 37, 386-398. https://doi.org/10.1016/j.it.2016.04.003

[7] De Onis, M., Blössner, M. and Borghi, E. (2016) WHO Global Database on Child Growth and Malnutrition. World Health Organization, 228-234.

[8] Khatab, K. (2010) Childhood Malnutrition in Egypt Using Geoadditive Gaussian and Latent Variable Models. American Journal of Tropical Medicine and Hygiene, 82, 653-663. https://doi.org/10.4269/ajtmh.2010.09-0501

[9] Kramer, C.V. and Allen, S. (2015) Malnutrition in Developing Countries. Paediatrics \& Child Health, 25, 422-427. https://doi.org/10.1016/j.paed.2015.04.002

[10] Bouillon, R. (2017) Comparative Analysis of Nutritional Guidelines for Vitamin D. Nature Reviews Endocrinology, 13, 466-479. https://doi.org/10.1038/nrendo.2017.31

[11] Creo, A.L., Thacher, T.D., Pettifor, J.M., Strand, M.A. and Fischer, P.R. (2017) Nutritional Rickets around the World: An Update. Paediatrics and International Child Health, 37, 84-98. https://doi.org/10.1080/20469047.2016.1248170

[12] Al Ghwass, M.M., Halawa, E.F., Sabry, S.M. and Ahmed, D. (2015) Iron Deficiency Anemia in an Egyptian Pediatric Population: A Cross-Sectional Study. Annals of African Medicine, 14, 25-31. https://doi.org/10.4103/1596-3519.148725

[13] Baxmann, A.C., Ahmed, M.S., Marques, N.C., Menon, V.B., Pereira, A.B., Kirsztajn, G.M. and Heilberg, I.P. (2008) Influence of Muscle Mass and Physical Activity on Serum and Urinary Creatinine and Serum Cystatin C. Clinical Journal of the American Society of Nephrology, 3, 348-354. https://doi.org/10.2215/CJN.02870707

[14] Munns, C.F., Shaw, N., Kiely, M., Specker, B.L., Thacher, T.D., Ozono, K., et al. (2016) Global Consensus Recommendations on Prevention and Management of Nutritional Rickets. Hormone Research in Paediatrics, 85, 83-106. https://doi.org/10.1159/000443136

[15] Holick, M.F., Binkley, N.C., Bischoff-Ferrari, H.A., Gordon, C.M., Hanley, D.A., Heaney, R.P., Murad, M.H. and Weaver, C.M. (2011) Evaluation, Treatment, and Prevention of Vitamin D Deficiency: An Endocrine Society Clinical Practice Guideline. Journal of Clinical Endocrinology \& Metabolism, 96, 1911-1930. https://doi.org/10.1210/jc.2011-0385

[16] El Koumi, M.A., Ali, Y.F. and Abd El Rahman, R.N. (2013) Impact of Maternal Vitamin D Status during Pregnancy on Neonatal Vitamin D Status. Turkish Journal of Pediatrics, 55, 371-377. 
[17] El Rifai, N.M., Abdel Moety, G.A., Gaafar, H.M. and Hamed, D.A. (2014) Vitamin D Deficiency in Egyptian Mothers and Their Neonates and Possible Related Factors. Journal of Maternal-Fetal \& Neonatal Medicine, 27, 1064-1068. https://doi.org/10.3109/14767058.2013.849240

[18] Lalor, M.K., Smith, S.G., Floyd, S., Gorak-Stolinska, P., Weir, R.E., Blitz, R., et al. (2010) Complex Cytokine Profiles Induced by BCG Vaccination in UK Infants. Vaccine, 28, 1635-1641. https://doi.org/10.1016/j.vaccine.2009.11.004

[19] Roy, A., Eisenhut, M., Harris, R.J., Rodrigues, L.C., Sridhar, S., Habermann, S., et al. (2014) Effect of BCG Vaccination against Mycobacterium tuberculosis Infection in Children: Systematic Review and Meta-Analysis. BMJ, 349, g4643. https://doi.org/10.1136/bmj.g4643

[20] Beshir, M.R., Zidan, A.E., El-Saadny, H.F., Ramadan, R.A., Karam, N.A., Amin, E.K., Mohamed, M.Z. and Abdelsamad, N.M. (2016) Evaluation of the Immune Response to Interferon Gamma Release Assay and Tuberculin Skin Test among BCG Vaccinated Children in East of Egypt: A Cross-Sectional Study. Medicine (Baltimore), 95, e3470. https://doi.org/10.1097/MD.0000000000003470

[21] Sadarangani, S.P., Whitaker, J.A. and Poland, G.A. (2015) "Let There Be Light": The Role of Vitamin D in the Immune Response to Vaccines. Expert Review of Vaccines, 14, 1427-1440. https://doi.org/10.1586/14760584.2015.1082426

[22] Lalor, M.K., Floyd, S., Gorak-Stolinska, P., Weir, R.E., Blitz, R., Branson, K., Fine, P.E. and Dockrell, H.M. (2011) BCG Vaccination: A Role for Vitamin D? PLoS ONE, 6, e16709. https://doi.org/10.1371/journal.pone.0016709

[23] Zitt, E., Sprenger-Mähr, H., Knoll, F., Neyer, U. and Lhotta, K. (2012) Vitamin D Deficiency Is Associated with Poor Response to Active Hepatitis B Immunisation in Patients with Chronic Kidney Disease. Vaccine, 30, 931-935. https://doi.org/10.1016/j.vaccine.2011.11.086

[24] Moe, S.M., Zekonis, M., Harezlak, J., Ambrosius, W.T., Gassensmith, C.M., Murphy, C.L., Russell, R.R. and Batiuk, T.D. (2001) A Placebo-Controlled Trial to Evaluate Immunomodulatory Effects of Paricalcitol. American Journal of Kidney Diseases, 38, 792-802.

[25] Zheng, Y., Li, X.G., Wang, Q.Z., Ma, A.G., Bygbjerg, I.C., Sun, Y.Y., et al. (2014) Enhancement of Vitamin A Combined Vitamin D Supplementation on Immune Response to Bacille Calmette-Guérin Vaccine Revaccinated in Chinese Infants. Asian Pacific Journal of Tropical Medicine, 7, 130-135.

https://doi.org/10.1016/S1995-7645(14)60008-0 